\title{
GERRARD WINSTANLEYS IKONOKLASME SOM IMMANENT UTOPI
}

\author{
GERRARD WINSTANLEY'S ICONOCLASM AS IMMANENT UTOPIA | In this ar- \\ ticle I analyse the utopian discourse of Gerrard Winstanley as an example of how utopia functions \\ as a social fiction. Winstanley was part of the radical Digger movement in the English Revolution in \\ the mid-1 $7^{\text {th }}$ century, and he has been regarded both as a religious mystic and as a precursor of later \\ communist thinkers. His last published text, The Law of Freedom in a Platform (1652), presents \\ an egalitarian utopian program based on democracy and collective ownership of land. It has been ar- \\ gued that this text represents a break from Winstanley's earlier religious and political writings because \\ of its focus on the institutional framework of the proposed utopian model. I argue, however, that it is \\ generally more productive to focus on the function of utopia and to see utopia as both a figurative and \\ conceptual discourse which combines a deconstruction of ideological contradictions with a production \\ of new sociopolitical representations. This approach allows us to analyse how Winstanley creates a \\ utopian discourse based on a "materialistic" iconoclasm which produces a dynamic, immanent utopia. \\ Rather than being a totalitarian vision, as some have argued, Winstanley's egalitarian and immanent \\ utopia dismantles the distinction between state and society. Utopia should be seen as a discourse \\ which, through its use of sociopolitical fictions, is able to bring out different sociopolitical dimensions \\ and potentials of a specific historical conjuncture by articulating the non-realized futures of history. \\ KEYWORDS | utopia, English Revolution, communism, \\ iconoclasm, religion, politics, historicization.
}

Utopier er sociopolitiske fiktioner, og de har i den egenskab et tvetydigt forhold til historien: På den ene side er en utopi altid et produkt af en konkret historisk kontekst og dens specifikke ideologiske problemstillinger; på den anden side forsøger utopien at repræsentere et samlet, sociopolitisk alternativ og i den forstand hæve sig op over den givne historiske horisont. På den måde kan utopier åbne for nogle historiske spændingsforhold, og det er især som bearbejdninger af sådanne brudflader, at utopier er interessante. Derfor er utopiske diskursers funktion heller ikke kun et spørgsmål om deres mulige evne til at tænke nyt, men har i mindst lige så høj grad at gøre med deres interaktion med allerede eksisterende ideologiske diskurser. Overordnet kan man sige, at utopiske fiktioner dels fungerer som en 
kritisk destabilisering af etablerede ideologier, dels som en positiv produktion af nye sociale repræsentationer. ${ }^{\mathrm{I}}$

Det er Gerrard Winstanleys utopiske tekster fra Den Engelske Revolution i midten af I60o-tallet et godt eksempel på, og derfor vil jeg i det følgende se nærmere på, hvordan Winstanleys utopiske diskurs fungerer. Winstanley (ca. I609-I676) udgav i 1652 sit utopiske program i The Law of Freedom in a Platform, hvor han argumenterede for en samfundsorden baseret på fælleseje og en form for demokrati. Men Winstanley udgav også andre tekster, der ikke på samme måde havde karakter af utopiske modeller. Jeg vil derfor samtidig argumentere for, at Winstanleys utopiske diskurs i sin helhed viser, at et begreb om utopiens funktion ikke kan begrænses til den klassiske model inspireret af Thomas Mores Utopia.

I utopistudier skelner man traditionelt mellem utopien som en litterær genre og det utopiske som en form for "impuls" (Jameson 3-4). Som Phillip Wegner skriver: "Enhver litteratur- og kulturvidenskabelig undersøgelse af utopiens problemstillinger må først skelne mellem utopien som en hermeneutik, dvs. som et fortolkningsskema, og utopien som en bestemt litterær genre" (II3). Det er ikke desto mindre en distinktion, som det kan være produktivt at bløde op. Derfor vil jeg i stedet fokusere på, hvordan en given diskurs kommer til at fungere utopisk ved at inkorporere billeder af sociopolitiske fiktioner i sin fremstilling. En utopisk diskurs vil typisk hverken være rent 'litterær' eller rent 'teoretisk', men vil operere med både fiktive, figurative og konceptuelle elementer. ${ }^{2}$ En sådan fleksibel tilgang til at forstå utopien - hvor det f.eks. ikke er nødvendigt at operere med en rigid opdeling i utopiske og ikkeutopiske tekster - vil give en bedre mulighed for at forstå, hvordan Winstanleys utopiske diskurs fungerer.

Borgerkrigene og revolutionen i England i I640'erne og -50'erne affødte mange nye og forskellige politiske ideer. F.eks. præsenterede republikaneren James Harrington i sin utopi The Commonwealth of Oceana fra I656 en samfundsmodel baseret på en integration af bestemte økonomiske ejendomsforhold, politisk repræsentation og militære strukturer. Den var bl.a. et svar til Thomas Hobbes, der i I65I havde udgivet sin Leviathan, hvor han beskrev den konfliktfyldte naturtilstand og argumenterede for behovet for en magtfuld suveræn til at holde sammen på samfundslegemets forskellige dele. Der var også Leveller-bevægelsen, som langt hen ad vejen baserede sine demokratiske, politiske krav på ideer om de engelske borgeres naturlige rettigheder. Den engelske revolution bidrog på den måde til den gradvise udvikling af den moderne stat og moderne opfattelser af politik, hvor spørgsmålet om forholdet mellem stat og samfund i stigende grad bliver omdrejningspunktet (Skinner 217ff).

I Mit utopibegreb er inspireret af bl.a. Fredric Jameson, Louis Marin og Ernst Bloch, som trods forskellige begrænsninger inviterer til en mere dynamisk forståelse af utopien end f.eks. Lyman Tower Sargent, der arbejder med en snæver definition af utopien (som en detaljeret beskrivelse af et alternativt samfund) samt med en noget ufleksibel skematisering af forskellige former for utopisme.

2 Den utopiske genre er i øvrigt i sig selv en form for diskursiv hybrid, der blander og grænser op til en række forskellige - og historisk skiftende - genrer, som Chordas argumenterer for ( $5 \mathrm{ff}$ ). 
En anderledes vision blev fremsat, da Gerrard Winstanley udgav The Law of Freedom - tre år efter at kongen Charles I var blevet henrettet, og året før Oliver Cromwell lod sig udnævne til Lord Protector. Winstanley var en af lederne af den radikale Digger-bevægelse, der havde en vision om et opgør med fattigdom og ulighed gennem fælles ejerskab af jorden. Diggerne oprettede bl.a. små kolonier, hvor medlemmerne dyrkede jorden sammen. Ifølge Winstanley var hele "Guds skaberværk" oprindeligt givet til menneskene i fællesskab.

Winstanley er blevet læst som både en nostalgisk, tilbageskuende drømmer og som en moderne tænker, der var forløber for senere kommunistiske teoretikere (Holstun, Communism I22f). Tilsvarende er det blevet diskuteret, om man primært skal forstå Winstanley som en religiøs eller en politisk tænker (Bradstock 82ff). Det er således et spørgsmål om, hvordan Winstanley - og Diggerne - skal historiseres. Jeg vil her forsøge at komme med et bud på, hvordan det kan gøres ved netop at fokusere på, hvordan den utopiske diskurs fungerer i Winstanleys tekster.

Winstanley skrev en lang række pamfletter over en relativt kort periode, der stort set var sammenfaldende med den mest radikale fase af Den Engelske Revolution $i$ årene $1647-52$. Han havde ikke været en synlig del af de politiske og religiøse konflikter i 1640'erne, og efter 1652 forsvandt han igen fra den offentlige scene. Det er ikke meget, man ved om Winstanleys liv før og efter hans aktive, politiske engagement i denne korte periode. Han kom formentlig fra en familie af håndværkere og småhandlende uden de store midler. Winstanley forsøgte selv at etablere sig med en skrædderforretning i London, men gik fallit i starten af I640'erne. Man ved ikke med sikkerhed, hvordan Winstanleys holdninger udviklede sig efter Diggerbevægelsens nederlag, men meget tyder på, at han i et vist omfang droppede sine radikale politiske og teologiske synspunkter. Der er dog nogle spor, der peger på, at han på et tidspunkt sluttede sig til kvækerne, der i slutningen af I650'erne var den største af de radikale, religiøse sekter i England, og hvis teologi i vid udstrækning stemte overens med Winstanleys. Men der er også andre spor, der antyder, at han sluttede fred med de officielle religiøse institutioner og blev medlem af den anglikanske kirke. ${ }^{3}$

Men denne relativt marginale figur er alligevel interessant. Først og fremmest i kraft af hans særegne utopiske diskurs, der skiller sig ud blandt revolutionens forskellige radikale stemmer.4 Winstanleys utopi udfordrer ikke kun det gamle monarki, men også det nye republikanske og puritanske styre. Jeg vil her se på, hvordan vi bedst kan forstå karakteren og betydningen af Winstanleys utopiske diskurs - herunder utopiens forhold til Den Engelske Revolutions politiske og ideologiske brudflader i øvrigt. Jeg vil primært fokusere på The Law of Freedom, men også inddrage nogle af de tidligere tekster. Ofte bliver der etableret et skel mellem Winstanleys utopiske model i The Law of Freedom og hans tidligere tekster, der ses som ikkeutopiske, fordi de ikke præsenterer et udfoldet bud på en alternativ sam-

Om Winstanleys liv og levned, se Alsop.

For nogle diskussioner af de litterære aspekter af Winstanleys tekster, se Loewenstein (47-9I) og Smith. 
fundsorden (Davis 169-203; Appelbaum 153-I7I). Men for at få et mere fuldstændigt og nuanceret billede af, hvordan Winstanleys utopi fungerer, er det nødvendigt at se The Law of Freedom som en del af en utopisk diskurs, der opererer i flere af Winstanleys tekster.

\section{Revolutionens brudflader}

Den engelske revolutions omvæltninger betød en udfordring af traditionelle hierarkier inden for såvel det politiske som det religiøse system. Det betød, at grundlæggende ideologiske problemstillinger blev sat til forhandling, selv om parlamentets puritanske og republikanske tilhængere ikke så sig selv som "revolutionære" i en moderne forstand. 5 De opfattede deres projekt som en genetablering af en oprindelig og mere retfærdig orden. Det drejede sig f.eks. om en tilbagevenden til tiden, før man kom under "det normanniske åg”, dvs. det monarki, der blev etableret efter Vilhelm Erobrerens invasion i I066. Det var som udgangspunkt den diskursive ramme, både radikale og moderate tilhængere af parlamentet tænkte, skrev og handlede inden for.

Samtidig udviklede revolutionens konflikter også deres egen dynamik. Den aktive inddragelse af nye politiske aktører betød en udvidelse af det politiske felt og den politiske offentlighed. I den proces blev såvel etablerede som nye politiske aktører tvunget til at overveje, hvad der var det fundamentale grundlag for en social orden. Hvem etablerer og garanterer loven? Er det Gud? Naturen? Eller er det mennesket og dets historie og traditioner? Og hvad betyder Gud, natur og menneske overhovedet i den sammenhæng, og hvad er deres indbyrdes relationer?

Både før og efter kongens henrettelse fandt der en kamp sted om udstrækningen og karakteren af parlamentets og folkets indflydelse på nationens politiske og religiøse anliggender. F.eks. i form af den radikale, demokratiske udfordring af ledelsen af den parlamentariske New Model Army, bl.a. i Putney-debatterne i 1647. Denne demokratiske udfordring kom især fra de såkaldte Levellers, der i en periode fandt opbakning blandt de menige i hæren. ${ }^{6}$

Digger-eksperimentet begyndte i april i649. For dem var det ikke nok at fjerne kongen i toppen af samfundet: "kongelig magt" skulle afskaffes i hele samfundet hvilket for Diggerne ville sige afskaffelse af f.eks. privat ejendomsret til jord, væk med præsteskab og tiende, og væk med advokater. Derfor gik Winstanley og hans lille gruppe i april 1649 i gang med at dyrke ubenyttet jord på St. George Hill nær Walton i Surrey. En del af baggrunden for Diggernes agitation var den private indhegning af jord, der tidligere havde været tilgængelig for alle. Denne udvikling, der havde fundet sted i England siden slutningen af I400-tallet, var et aspekt af landbrugets udvikling i en gradvist mere kapitalistisk retning. Diggerne besatte dog ikke direkte privat jord, men slog sig ned på fælles tilgængelige områder,

5 For en diskussion af, hvordan betydningen af ordet "revolution" udviklede sig i perioden, se Hill, "Revolution".

6 For en diskussion af de radikale strømninger i New Model Army, se Holstun, Ehud 192-256. 
idet de argumenterede for, at disse efter parlamentets sejr måtte tilhøre folket i fællesskab. Winstanley argumenterede for, at kampen for et mere retfærdigt samfund måtte være fredelig og ikkevoldelig, og Diggernes dyrkning af jorden var $i$ høj grad en symbolsk handling, der skulle tjene som et inspirerende eksempel for andre.

Winstanley skrev de fleste af sine tekster før afslutningen af Digger-eksperimentet. The Law of Freedom udkom næsten to år efter kommunernes opløsning.7 I forordet dedikerer Winstanley The Law of Freedom til Cromwell og henvender sig således direkte til den på det tidspunkt kommende Lord Protector med en opfordring til ham om at realisere Winstanleys samfundsvision. Winstanley skriver: "Og nu har jeg sat dette lys foran din dør, for du har magten $i$ din hånd, og i den anden får du nu muligheden for at handle til gavn for fælles frihed, hvis du vil: Jeg har ingen magt" (Winstanley, Bd. 2, 288). Ved at appellere til Cromwell som den eneste, der har magten til at realisere utopien, ekspliciterer Winstanley skellet mellem den utopiske fiktion og den politiske magt. Han markerer, at utopien har karakter af en diskursiv, ideologisk praksis, der er distanceret fra staten og den politiske kamp om magten. Men netop den distance er også det, der placerer den utopiske diskurs $i$ en særlig position i relation til revolutionens konflikter. Utopien etablerer sig på den måde som et fiktivt rum, hvor det er muligt at mobilisere og reflektere de forskellige ideologiske spor og splittelser, der er til stede i revolutionens historiske åbning. Og som nævnt kredser disse ikke mindst om genforhandlingerne af det ideologiske fundament for den sociale orden. En læsning af Winstanleys utopi (eller en hvilken som helst anden utopi for den sags skyld), må derfor stille sig det centrale spørgsmål om, hvordan den utopiske fiktion fremstiller både grundlaget for og opbygningen af en alternativ social orden.

\section{Winstanleys ikonoklastiske kommunisme}

Som nævnt bliver The Law of Freedom ofte set som et både stilistisk og indholdsmæssigt brud med Winstanleys tidligere teksters mere farverige billedsprog og "anarkistiske" politik. ${ }^{8}$ Umiddelbart er der også tale om et fokusskifte, selv om omdrejningspunktet gennemgående er det fælles ejerskab til jorden; for hvor de tidligere tekster vagt beskriver en eskatologisk idé om, at "Kristus rejser sig i menneskene", tilbyder The Law of Freedom en mere konkret institutionel ramme for Winstanleys sociale vision. Hovedtrækkene i det samfund, Winstanley beskriver, er: demokratiske valg til en række forskellige poster på lokalt og nationalt niveau, herunder dommere og et parlament; alle skal være tvunget til at arbejde, f.eks. med dyrkning af jorden eller som håndværkere, og man bliver straffet, hvis man ikke på den måde bidrager til samfundet; fødevarer og andre produkter opbevares

7 Winstanley skriver dog i forordet ( $B d .2$ 287-288), at han har haft teksten liggende i længere tid, så umiddelbart er det ikke til at vide præcist, hvilke dele af teksten der er skrevet hvornår.

8 Darren Webb argumenterer dog for, at der er en grundlæggende kontinuitet $\mathrm{i}$ Winstanleys tænkning. 
$i$ lagerbygninger, hvor de er frit tilgængelige; uddannelse og forskning organiseres praktisk og rationelt for at sikre, at de unge lærer et håndværk, og at samfundet og arbejdets effektivitet løbende forbedres.

Winstanleys tematisering af forholdet mellem på den ene side statens udformning og på den anden side samfundets sociale og økonomiske organisering er her bemærkelsesværdig. Han sætter lighedstegn mellem den traditionelle kongemagt og markedets "køb og salg", som gradvist var ved at ændre Englands landskab og sociale strukturer - samtidig med at revolutionen så ud til at transformere staten fra en monarkisk til en republikansk styreform. Winstanley argumenterer igen og igen for, at når staten er blevet "fri", så må resten af samfundet følge i samme spor. Når staten er blevet et fælles anliggende, skal resten af samfundet også være det. Her gik Winstanley videre end f.eks. Levellers, der stillede krav til det politiske system, men ikke til de sociale og økonomiske strukturer. Samtidig kan Winstanleys program ikke reduceres til et ønske om at vende tilbage til en tidligere økonomisk orden. Hans argumenter og sprogbrug ligger således flere steder på linje med de formuleringer, man så hos samtidens tilhængere af et moderniseret og effektiviseret landbrug. 9

I slutningen af The Law of Freedom opstiller Winstanley flere end tres forskellige, konkrete love, der skal danne grundlaget for dette frie og retfærdige samfund, hvor der er gjort op med alle former for kongemagt. Her ser han tilsyneladende en demokratisk organiseret stat som omdrejningspunktet for indførelsen af en ny, kollektiv samfundsorden. Det synes at være i modsætning til den modstand mod Loven som sådan, som man finder visse steder i hans øvrige tekster (Hill, Liberty 289; 295). Den større rolle, statslige institutioner, love og regler spiller i The Law of Freedom er blevet tolket som et udtryk for Winstanleys desillusion som følge af Digger-bevægelsens nederlag. Det utopiske program er også blevet set som en statisk og totalitær samfundsmodel (Davis I93; 202-203). Men her vil jeg som udgangspunkt indvende, at det hverken er entydigt, hvilken form for eskatologi der er tale om i de tidlige tekster, eller hvilken betydning den præsenterede statsmodel skal tillægges i The Law of Freedom.

Så hvordan fremstiller Winstanleys utopi grundlaget for en fri og retfærdig social orden? Hvordan opererer utopiens fiktion med de forskellige ideologiske bud på samfundets ideologiske fundament? Og hvordan forestiller Winstanley sig i den forbindelse forholdet mellem staten og samfundet - det politiske system og den sociale orden? Er der f.eks. behov for love og stat? Det står ikke helt klart, og der findes tvetydigheder i både The Law of Freedom og i de tidligere tekster. Så selv om der er forskelle mellem Winstanleys forskellige tekster, er det her mere relevant at læse The Law of Freedom i forlængelse af de forudgående skrifter. Det vil give det

9 Se f.eks. Winstanleys forslag til indretningen af uddannelser og tilskyndelse til nye opfindelser (Winstanley, $B d$. 2, 354ff). Se også Holstuns diskussion, som bl.a. relaterer Winstanleys ideer til Francis Bacons videnskabelige tilgang til verden (Ehud 397-4II). 
bedste billede af, hvordan Winstanleys utopiske diskurs fungerer i både The Law of Freedom og i de tidligere teologiske og politiske pamfletter.

\section{Materialistisk ikonoklasme}

Winstanleys utopiske figurer er gennemgående kendetegnet ved den måde, hvorpå forskellige billeder og beskrivelser af mennesket, samfundet, naturen og Gud overlejrer hinanden. I kraft af de konstellationer, der herigennem bliver etableret, producerer Winstanleys tekster en ikonoklastisk logik, der destabiliserer etablerede forestillinger om både den sociale ordens organisering og historiens tidslige forløb. Nogle af de niveauer, Winstanley opererer med i sine tekster - naturen, Gud, samfundet, den menneskelige krop - spiller f.eks. sammen i denne beskrivelse fra starten af The Law of Freedom, hvor Winstanley definerer frihed:

"Sand frihed skal findes der, hvorfra mennesket modtager sin næring og opretholdelsen af livet, og det er i brugen af jorden. For lige så vel som mennesket består af skaberværkets fire materialer, ild, vand, jord og luft; så bliver han også holdt i live af disse fires samlede legemer, som er jordens frugter; og han kan ikke leve uden dem. For hvis man tager den frie brug af disse væk, forfalder kroppen, og ånden bliver trælbundet og forgår til sidst.” (Winstanley, Bd. 2, 295)

Her knyttes naturen og menneskets krop sammen, i kraft af at begge består af de samme materialer, og med Winstanleys særegne definition, består menneskets frihed altså i den konkrete realisering af denne forbindelse med naturen. Samtidig er naturen Guds skaberværk, og Gud er - som Winstanley skriver flere andre steder - til stede i skaberværket. Han skriver f.eks.: "At kende naturens hemmeligheder, er at kende Guds gerninger; og at kende Guds virke i skaberværket er at kende Gud selv, for Gud er til stede i ethvert synligt værk eller legeme” (Winstanley, Bd. 2, 342).

Det afgørende er her de ligheds- og nærhedsrelationer, Winstanley i sine tekster får etableret mellem Gud, naturen, jorden, kroppen, mennesket og samfundet. De forskellige niveauer af virkeligheden bliver filtret ind i hinanden, og samtidig opløses de hierarkier, som traditionelt strukturerede de ideologiske forestillinger om forholdet mellem Gud, naturen og den sociale orden. I stedet placerer Winstanley det daglige arbejde med jorden samt erkendelsen af naturen i centrum af sit verdensbillede. Winstanley bruger f.eks. eksplicit Fornuft som synonym for Gud. Og ligesom erkendelsen af naturen svarer til at studere Gud, bliver det fysiske arbejde også forbundet med Bibelens tekst. Som Winstanley skriver i Fire in the Bush: "Bibelens hellige skrift blev skrevet af erfarne hænder, der tilhørte hyrder, bønder, fiskere og andre af verdens laverestående mænd; og universiteternes lærde har taget disse mænds skrifter; og de tildækker deres simple sprog med deres formørkede fortolkninger" (Winstanley, Bd. 2, 200).

Derfor er arbejdende, fattige folk heller ikke afskåret fra Guds sandhed. Tværti- 
mod er den enkeltes "indre lys" ifølge Winstanley den privilegerede adgang til Gud - i modsætning til det præsteskab, der forsøger at monopolisere retten til at fortolke Skriften.' I forlængelse heraf læser Winstanley, der også hævdede at have modtaget sit bud om at dyrke jorden kollektivt direkte fra Gud, da heller ikke Bibelen bogstaveligt, men fortolker de bibelske historier allegorisk på sine egne, idiosynkratiske måder.

Winstanley er konstant kreativ i sin tolkning af forholdet mellem bibelske betydninger og filosofiske og politiske begreber. På den måde producerer hans utopiske diskurs hele tiden betydningsmæssige forskydninger, som bidrager til at nedbryde hierarkier og grænser. F.eks. kommer den nævnte metonymiske kæde af relationer mellem Gud, Guds skaberværk og menneskets arbejde til at antage karakter af et lighedstegn, der sætter Gud lig med fornuften og hermed menneskets erkendelse af og arbejde med den materielle verden. Her er 'Gud' ikke længere lig med hierarki og monarki, men tværtimod med en dynamisk og egalitær logik, der til stadighed udfordrer etablerede og statiske systemer.

Samtidig opererer Winstanleys figurative fremstilling gennemgående med en binær logik, hvor vi overalt ser den samme konflikt mellem to forskellige principper gå igen. Winstanley beskriver det bl.a. som en konflikt mellem common preservation og self-preservation - eller mellem righteousness og unrighteousness. Som illustration benytter han bl.a. de forhold mellem ældre og yngre brødre, som optræder i Bibelen - fra Kain og Abel og frem. Her repræsenterer de ældre brødre de rige og jordbesiddende, der frarøver de yngre deres naturlige, gudgivne ret til jorden. I tråd med den binære struktur fremstilles monarki, præsteskab og advokater som parasitiske elementer på et grundlæggende sundt og naturligt samfundslegeme. De repræsenterer stilstand og korruption i modsætning til Guds skaberværk, der er karakteriseret af liv og bevægelse. Winstanley ser den frie samfundsorden som en dynamisk organisme, hvor f.eks. de valgte repræsentanter jævnligt bliver udskiftet: "Store embeder $i$ et rige og en har har andret mange indfulde mands karakter. Og naturen viser os, at stillestaiende vand fordarves; mens vand, der løber, forbliver friskt" (Winstanley, Bd. 2, 3I7).

En egalitær politisk teologi og billedet af et skaberværk i stadig bevægelse fungerer på den måde som drivkraften i Winstanleys kritik af "kongelig magt". Winstanleys diskurs lægger sig i forlængelse af den ikonoklastiske kritik af kirkelige og verdslige autoriteter og institutioner, som blev fremført af revolutionens radikale puritanere, f.eks. John Milton. Men samtidig viderefører Winstanley den ikonoklastiske logik, når han fremstiller et samfunds- og verdensbillede, der omfortolker forholdene mellem Gud, mennesker og natur. I Winstanleys fortolkning udvider begrebet "kongelig magt" sig fra at betegne en konkret politisk institution til at beskrive et generelt princip i både historien, samfundet og naturen. Det er et princip, der ud over monarkiet også forbindes med præsteskabet og advokatstanden

Io Her er Winstanley på linje med mange andre radikale protestantiske strømninger - bl.a. kvækerne, som blev en stor bevægelse i løbet af I650'erne. 
samt privat ejendom og handel: "Den kongelige styreform regerer jorden gennem det bedrageriske redskab, der er køb og salg” (Winstanley, $B d .2$, 305).

Det ikonoklastiske projekt bliver derfor langt mere omfattende. Det er "kongemagt" i alle former og på alle niveauer, der skal ryddes væk. Og samtidig er ikonoklasmen ikke blot et "åndeligt" projekt - som det langt hen ad vejen er for f.eks. Milton - men i høj grad også et materielt og socialt. Det fælles arbejde med jorden har karakter af en "materialistisk" ikonoklastisk praksis, hvorigennem monarkiets og markedets idoler undergraves, og meningen med Guds skaberværk realiseres konkret gennem praktisk arbejde. Hos Winstanley sker der altså en udvidelse og en konkretisering af den figurative ikonoklasme. På den måde adskiller Winstanleys ikonoklasme sig både fra Miltons indadvendte, intellektuelle ikonoklasme og fra den rent symbolsk orienterede ikonoklasme, der bl.a. bestod i fjernelsen af afguds- og billeddyrkende elementer i kirkerne og det offentlige rum. Winstanleys materialistiske ikonoklasme kommer derfor også til at fungere som en ideologisk nedbrydning af de grænser, den sociale orden etablerer mellem f.eks. dem, der ejer jord, og dem, der ikke gør. Det er en ikonoklasme, der også søger at udfordre ejendomsforholdenes kortlægning og opdeling af den sociale ordens geografi.

\section{Immanent utopi}

Spørgsmålet om den private ejendomsret optager den centrale plads hos Winstanley, der også sætter lighedstegn mellem Syndefaldet og etableringen af privat ejendom: "Da mennesket begyndte at købe og sælge, da faldt det fra sin uskyld; for da begyndte de at undertrykke hinanden og snyde hinanden for deres medfødte ret til skaberværket" (Winstanley, $B d$. 2, 289). Betydningen og karakteren af Syndefaldet bliver således også omtolket. Og på samme måde som Winstanleys diskurs hele tiden forskyder relationerne mellem det naturlige, guddommelige og menneskelige, så destabiliseres også forholdene mellem fortid, nutid og fremtid. Det samtidige overlejres af og forbindes med både for- og fremtider, idet hverken Syndefaldets mytologiske fortid eller den apokalyptiske fremtid og Guds rige er fjerne tilstande, men tværtimod ganske nærværende.

Winstanleys utopiske diskurs opererer med flere forskellige "guldaldre", der på forskellige måder har karakter af før-syndefaldstilstande, som er gået tabt takket være kongemagt og privat ejendom: der er Guds oprindelige skaberværk; der er det bibelske Israel under Moses; der er England før den normanniske invasion. Samtidig er Kristi genkomst en begivenhed, hvis umiddelbare nærvær registreres af Winstanley. Ikke mindst i Fire in the Bush trækker han på Bibelens eskatologiske fortællinger, især Johannes' Åbenbaring og Daniels Bog. I Winstanleys kreative læsning udlægges de forskellige uhyrer, der optræder i disse tekster, som billeder på præster, advokater, konger osv. (Winstanley, Bd. 2, I89ff; Loewenstein, 72ff).

Kampen mellem Syndefaldets self-preservation og Guds common preservation er således allerede i gang, og disse forskellige "tider" synes derfor at eksistere side 
om side som forskellige aspekter af den samme tid. Det er derfor heller ikke et spørgsmål om passivt at afvente Kristi genkomst, for Kristus er ifølge Winstanley allerede i færd med at "rejse sig i menneskene" - tilsyneladende i en gradvis proces. Denne formulering, hvis præcise betydning forbliver lettere gådefuld, går igen i Winstanleys tekster. På den måde fremstiller Winstanley Guds rige både som en indre realitet (hvor Kristus er i alle) og som en ydre samfundsforandring. Det afgørende for Winstanley er at fremme det frie fællesskab, som han identificerer med Guds skaberværk og Kristi genkomst. Og det gøres først og fremmest gennem arbejdet med jorden. Samtidig forbliver det dog uklart, om Winstanley selv mener, at han følger eller foregriber Kristi genkomst.

Winstanleys utopiske diskurs er her hverken entydigt nostalgisk (som de konservative kritikere af den private indhegning af jord) eller entydigt fremskridtsorienteret (som tilhængerne af en modernisering af landbruget). Det gælder både hans teologi og hans politiske og sociale program. Det, der først og fremmest er karakteristisk, er den måde, hvorpå Winstanley hele tiden skaber dynamiske relationer, billed- og betydningsdannelser ud af revolutionens politiske og religiøse diskurser. Det væsentlige ved Winstanleys utopiske figur er derfor dens ikonoklastiske logik, der etablerer nye diskursive forbindelser og producerer en række nyfortolkninger af de politisk-religiøse billeder og metaforer, Winstanley mobiliserer.

Winstanleys diskurs producerer herigennem sin egen sociale fiktion, bl.a. gennem disse billedlige overlejringer, hvor naturen, samfundet, mennesket og Gud både flettes ind i hinanden og mimer hinandens strukturer og egenskaber. Det er som nævnt en social fiktion, hvor Guds skaberværk - jorden - er givet til alle mennesker i fællesskab, og hvor Gud er til stede i sit skaberværk og erkendes gennem arbejdet med det. I denne fiktion forhandler den ikonoklastiske logik hele tiden forholdet mellem den historiske tidslighed og den sociale rumlighed. Realiseringen af utopien er derfor altid undervejs. Winstanleys utopiske fiktion har således karakter af en immanent utopi, der både er en del af virkeligheden og endnu ikke er fuldt ud realiseret.

I kraft af den ikonoklastiske og egalitære logik i Winstanleys utopiske diskurs bliver utopiens centrale funktion en dekonstruktion af etablerede forhold mellem årsager og virkninger, indre og ydre rum, fortider og fremtider. Det er både sociale hierarkier og geografier og en struktureret historisk tidslighed, der bliver nedbrudt. I stedet for at etablere en central, politisk magt som omdrejningspunktet for den sociale orden bliver det fælles arbejde med jorden sat i centrum. Og tilsvarende nedbrydes grænserne mellem det verdslige og det guddommelige og mellem udvalgte og fordømte.

På den måde destabiliserer Winstanleys utopiske ikonoklasme revolutionens forskellige ideologiske fiktioner - både religiøse og politiske. Den utopiske diskurs fungerer altså som en konstant, kreativ forhandling af revolutionens ideologiske forestillinger om et stabilt fundament for den sociale orden. Og fordi forestillingen om et stabilt, transcendent punkt undermineres, kommer jagten på et grundlag for den sociale orden også til at antage en anden karakter hos Winstanley. Det gud- 
dommelige, det naturlige og det menneskelige sættes i spil i forhold til hinanden, men uden at der etableres et entydigt, ideologisk grundlag.

\section{Frihedens lov}

Det er derfor også i det lys, man skal læse det utopiske program i The Law of Freedom - og den paradoksale status, Loven har i hans utopiske diskurs, og som kommer tydeligst til udtryk i denne tekst. Som nævnt sikrer Winstanleys forslag til institutionelle rammer bl.a. jævnlige valg til politiske poster og gør det obligatorisk at bidrage til samfundet gennem arbejde, ligesom der opstilles en række sanktioner for at bryde de fælles regler. Og som også nævnt synes dette system umiddelbart at stå i modsætning til Winstanleys tidligere utopiske formuleringer - f.eks. i The New Law of Righteousness: "Der vil ikke være noget behov for advokater, fængsler eller redskaber til at afstraffe hinanden, for som en del af skaberværket skal alle gå omkring og handle retfærdigt, og der vil ikke være tiggere eller nogen grund til beklagelse" (Winstanley, Bd. I, 506).

Det er her væsentligt, at Winstanley forstår loven som både en indre og en ydre realitet: på den ene side er der Guds/naturens lov og på den anden side den nedskrevne, menneskeskabte lov. Men forholdet mellem de to er ikke entydigt. Som han skriver: "For alle skal kende loven, og alle skal adlyde loven; for den vil stå skrevet i alles hjerter; og alle der er underlagt fornuftens lov, skal nyde godt af at være dens sønner. Og det vil sige i et ydre fællesskab, at arbejde sammen, at spise brød sammen" (Winstanley, Bd. I, 520-52I). Her er loven tilsyneladende både overflødig og nødvendig, og det samme spændingsforhold går igen i The Law of Freedom, hvor Winstanley også beskriver forholdet mellem naturens lov og menneskets lov (Winstanley, Bd. 2, 304-3I4; 366-369). Winstanley fastholder både, at den menneskeskabte lov udspringer af naturloven (der f.eks. betyder at 'Kristus rejser sig i menneskene'), og at der er behov for nedskrevne love til at regulere samfundet. Der er således et paradoksalt, men dynamisk forhold mellem lovens forskellige betydninger i Winstanleys utopiske diskurs, hvor det forbliver uklart, hvad der er årsag, og hvad der er virkning. Winstanleys utopiske og materialistiske ikonoklasme betyder på den måde også en stadig omtolkning af forståelsen af loven. Og det er denne paradoksale karakter, der er det væsentlige i Winstanleys utopiske program - ikke den institutionelle model som sådan.II Det afgørende i Winstanleys immanente utopi er stadig betydningen af de dynamiske ligheds- og nærhedsrelationer mellem mennesker, natur, Gud og samfund. Winstanleys utopiske diskurs - og hans utopiske model - skal derfor ses som led i en dynamisk proces, hvor det kommunistiske Gudsrige gradvist udbredes.

Den immanente logik i Winstanleys utopiske diskurs betyder som nævnt en

II Også i tidlige tekster som The New Law of Righteousness argumenterer Winstanley for sanktioner som dem, der foreslås i The Law of Freedom (se f.eks. Winstanley, Bd. I, 508). Sidstnævnte repræsenterer således ikke et radikalt brud på det punkt. 
opløsning af traditionelle forhold mellem bl.a. årsager og virkninger og en stadig omtolkning af politiske og religiøse billeder og begreber, hvor ingen af de forskellige ideologiske fiktioner får lov til at blive stående som et transcendent fundament for den sociale orden. Hvis der er et fundament for Winstanleys utopi, er det således denne kreative, ikonoklastiske praksis, der står som den gennemgående drivkraft i både hans tidlige tekster og i The Law of Freedom. Det er omdrejningspunktet for Winstanleys positive fremstilling af en ny form for social orden, der er egalitær og baseret på en kollektiv og produktiv social praksis. Derfor ser vi også, at mens Winstanleys utopiske diskurs på den ene side tematiserer forholdet mellem stat og samfund, dekonstruerer hans utopiske ikonoklasme på den anden side skellet mellem statens love og samfundets fællesskab. Det politiske og det sociale bliver to sider af samme sag i den stadige forskydning af betydninger i Winstanleys utopiske diskurs, hvor omdrejningspunktet er den sociale og produktive praksis i sig selv.

Samtidig er Winstanleys egalitære utopi ikke kun baseret på kollektivisme, men rummer også antydningerne af et universalistisk perspektiv, idet Winstanleys materialistiske ikonoklasme samtidig betyder en nedrivning af den sociale ordens grænsedragninger. Dels udfordrer han den private ejendoms opdelinger, dels åbner han for, at Kristus i sidste ende vil rejse sig i alle mennesker og $\mathrm{i}$ alle nationer (Winstanley, $B d .2$, 30I).

\section{Den utopiske diskurs og historiens horisont}

Winstanley påpeger selv $\mathrm{i}$ The Law of Freedom, at det program, han skitserer, ikke er en færdig model. Den er blot et udkast, der kan arbejdes videre på, og han sammenligner sin tekst med et stykke tømmer, der skal forarbejdes, og som med tiden kan indgå i et færdigt bygningsværk: "Selv om dette program må være som et stykke groft tilhugget tømmer, så kan de omhyggelige arbejdsmænd tage det og omdanne det til et smukt bygningsværk" (Winstanley, Bd. 2, 288). Winstanley søger her at etablere en dialog med en offentlighed og italesætter utopiens realisering som et fælles projekt. Det utopiske program er derfor blot et led i en proces. I forlængelse heraf fortsætter Winstanley med at beskrive sin tekst: "Den er som en fattig mand, som kommer til din dør i lasede, landlige klæder, og som er uvidende om de lærde borgeres foranderlige skikke og manerer; fjern det klodsede sprog, for under det kan du se skønhed” (Winstanley, Bd. 2, 288). Ligesom teksten må viderebearbejdes af 'arbejdende hænder', kan den samtidig sammenlignes med den fattige mand, der fra samfundets bund kan fortælle sandheden om Gudsriget uden overflødig pynt.

Winstanley iscenesætter sin tekst som en stemme fra folket, som et ubearbejdet og råt materiale. Og han fremstiller i teksten sig selv som en, der taler på vegne af folket. Samtidig henvender han sig som nævnt eksplicit til Cromwell med sin appel og med konstateringen af, at Cromwell har 'al magten'. Men selv om Cromwell måske nok har den politiske magt, er Winstanley ikke mere ydmyg, end at han finder det passende at give hærlederen denne advarsel: "Hele skaberværkets 
ånd (som er Gud) er i færd med reformationen af verden, og han vil fortsætte sit værk. For hvis han ikke ville skåne konger, som så længe har siddet ved hans højre hånd og regeret verden, vil han heller ikke tage hensyn til dig, medmindre dine handlinger bliver fundet at være mere retfærdige end kongens” (Winstanley, $B d$. 2, 280).

Winstanleys utopiske projekt er altså ikke sammenfaldende med de republikanske puritaneres, og idet han samtidig søger at konstruere en udsigelsesposition, der placerer folket i modsætning til hærens leder, markerer han, at revolutionen fortsat rummer en splittelse mellem forskellige subjekters praksisser og positioner. Det er i dette spændingsfelt mellem revolutionens forskellige og uafklarede subjektpositioner, at den utopiske diskurs kan formå at erobre sig en plads, hvorfra paradokser og potentialer i de ideologiske diskurser kan sættes i spil. På den måde kan man sige, at utopien søger at holde fast i revolutionen som en åbning af nye historiske horisonter. Og her opererer utopien med to forskellige historiske funktioner: for det første en kritisk funktion, idet utopien destabiliserer de forskellige ideologiske fiktioner, den inkorporerer i sin diskurs; for det andet en kreativ funktion, der etablerer en positiv fremstilling af en ny form for social orden - i dette tilfælde et egalitært, demokratisk og kollektivt samfund. Det er i kraft af disse funktioner, at en utopisk diskurs som Winstanleys formår at udfordre historiens, revolutionens og de ideologiske diskursers horisonter.

I den historiske åbning, som revolutionens konflikter skaber, bliver det på den måde muligt for en figur som Winstanley at producere en utopisk diskurs, der artikulerer nogle af den historiske konjunkturs forskellige sociopolitiske dimensioner og potentialer. Den utopiske diskurs fremstiller nye sider af historien ved at artikulere de fremtider, der ikke blev til noget (jf. Bloch). Som sådan er Winstanleys utopiske diskurs hverken "traditionel" eller "moderne", men skriver sig ind i en ujævn historisk udvikling, hvor en række forskellige fortider og mulige fremtider bliver sat i spil i det samme ideologiske rum. Samtidig med at republikanere og radikale på den ene side kæmper for politiske rettigheder, og bl.a. Hobbes og tilhængere af monarkiet på den anden side beskriver statens nødvendige dominans over samfundet, kortslutter Winstanleys utopiske diskurs modsætningen mellem samfund og stat, idet menneskets kollektive praksis gøres til omdrejningspunktet for en egalitær vision. I Winstanleys fremstilling er frihed ikke negativt defineret, men skal i stedet realiseres positivt gennem det fælles arbejde med jorden.

Winstanley fremstiller på den måde en utopi, der er radikalt forskellig fra samtidens historiske horisont. Og utopiens immanente karakter kommer samtidig til at stå som en udfordring af historien som den senere udviklede sig, idet den ikke kun repræsenterer et alternativ til monarkiet, men også til republikanske og senere liberale - traditioner. Mens visse aspekter af Den Engelske Revolution pegede frem mod både etableringen af det konstitutionelle monarki efter I688 og udviklingen af det engelske imperium, så demonstrerer Winstanleys utopiske diskurs, at revolutionen også rummede andre dimensioner og historiske per- 
spektiver. Utopien holder her fast $i$, at historien og den sociale orden er stadigt foranderlig.

Ved at operere med fleksibel og flerdimensionel forståelse af utopien, der fokuserer på den utopiske diskurs' funktioner, bliver det altså muligt at se, hvordan Winstanley producerer en dynamisk, immanent utopi, der bidrager til billedet af Den Engelske Revolutions ideologiske, politiske og kulturelle brudflader - i stedet for blot at se ham som enten en religiøs mystiker eller forfatteren til en statisk og totalitær samfundsmodel. Den tilgang til utopiens historiske karakter og funktion, jeg har anvendt her, forsøger på den måde at få greb om, hvordan utopiske fiktioner både fungerer som destabiliseringer af ideologiske fiktioner og som artikulationer af nye sociopolitiske diskurser og visioner. Det er derfor en tilgang, der generelt tilbyder en potentielt nuance- og perspektivrig forståelse af utopien som et diskursivt og historisk fænomen, der er i stand til at bidrage med nye vinkler på relationerne mellem litteratur, politik og historie.

\section{LITTERATURLISTE}

Alsop, James D. “Gerrard Winstanley: What Do We Know of His Life?”. Prose Studies: History, Theory, Criticism 22:2 (1999): 19-36.

Appelbaum, Robert. Literature and Utopian Politics in Seventeenth-Century England. Cambridge: Cambridge University Press, 2002.

Bloch, Ernst. “Anticiperet realitet - hvad er utopisk tænkning, og hvad kan den?”. Ernst Bloch - en introduktion. Red. Jørn Erslev Andersen et al. Århus: Modtryk, I982: 25-36.

Bradstock, Andrew. Faith in the Revolution. The Political Theologies of Müntzer and Winstanley. London: SPCK, I997.

Chordas, Nina. Forms in Early Modern Utopias. The Ethnography of Perfection. Farnham: Ashgate, 2010.

Davis, J.C. Utopia and the Ideal Society. A Study of English utopian writing 15I6-I700. Cambridge: Cambridge University Press, I98I.

Hill, Christopher. “The Word 'Revolution' in Seventeenth-Century England”. For Veronica Wedgwood these Studies in Seventeenth-Century History. Red. Richard Ollard og Pamela Tudor-Craig. London: Collins, I986.

Hill, Christopher. Liberty against the law. Some seventeenth-century controversies. London: Penguin, I996.

Holstun, James. "Communism, George Hill and the Mir: Was Marx a Nineteenth-Century

Winstanleyan?”. Prose Studies: History, Theory, Criticism 22:2 (I999): I2I-I48.

Holstun, James. Ehud's Dagger. Class Struggle in the English Revolution, London: Verso, 200.

Jameson, Fredric. Archaeologies of the Future, London: Verso, 2005.

Loewenstein, David. Representing Revolution in Milton and his Contemporaries. Cambridge: Cambridge University Press, 200I.

Marin, Louis. Utopics. The Semiological Play of Textual Spaces. New York: Humanity Books, I984.

Sargent, Lyman Tower. "The Three Faces of Utopianism Revisited”. Utopian Studies 5:I (I994): I-37. 
Skinner, Quentin. Politik og historie. Red. Frank Beck Lassen og Mikkel Thorup. København: Hans Reitzels Forlag, 2009.

Smith, Nigel. "Gerrard Winstanley and the literature of revolution". Prose Studies: History, Theory, Criticism 22:2 (1999): 47-60.

Webb, Darren. "The Bitter Product of Defeat? Reflections on Winstanley's Law of Freedom". Political Studies 52 (2004): 199-215.

Wegner, Phillip. "Here or Nowhere: Utopia, Modernity, and Totality". Utopia Method Vision. The Use Value of Social Dreaming. Red. Tom Moylan og Rafaella Baccolini. Bern: Peter Lang, 2007. II3-I29.

Winstanley, Gerrard. The Complete Works of Gerrard Winstanley. 2 Bd. Red. Thomas Corns, Ann Hughes og David Loewenstein. Oxford: Oxford University Press, 2009. 
DETTE MATERIALE ER OPHAVSRETSLIGT BESKYTTET OG MA IKKE VIDEREGIVES 